\title{
Comparison of Simplified and Detailed Window Models in Energy Simulations
}

\author{
Martin Thalfeldt ${ }^{2}$, Jarek Kurnitski ${ }^{2}$, Hendrik Voll ${ }^{3}$, \\ ${ }^{1,2,3}$ Tallinn University of Technology
}

\begin{abstract}
The purpose of this study is to quantify the gap between the calculated energy need of a building model with simplified and detailed windows and suggest a method for reducing the gap. We composed a model of a detached house in the cold climate of Estonia and studied its energy needs with triple and quadruple windows. Standard window models resulted in heating need lower by up to $7 \%$ and cooling need higher by up to $23 \%$. In case of triple windows multiplying the $U$-value of standard window models by 1.15 minimized the mismatch in the calculated energy needs with different window models.
\end{abstract}

Keywords - Energy simulations, windows, façade design

\section{INTRODUCTION}

Several countries in the European Union require running energy simulations to prove new buildings compliance with energy performance minimum requirements. Expected energy use is calculated, however it rarely complies with actual measured consumption. Reducing the gap between the calculated and measured energy is currently one of the main problems faced in the field of building energy analyses.

Façades have a large effect on the building energy use while the size and properties of glazed areas are especially important. Numerous papers on optimizing window areas have been published. Thalfeldt [1] and Pikas [2] studied cold climate office building facades with several glazing types and optimized the total cost of investment and energy over a 20 year period. They concluded that triple windows with areas that assure the required daylight factor $2 \%$ is the financially feasible solution and in case of four and five pane windows, larger window areas could be used to optimize energy use. Persson et al. [3] studied the window sizes of dwellings in a cold climate and pointed out that the window size of south-oriented windows does not have a remarkable effect on heating needs and smaller windows might be reasonable to reduce over-heating and cooling needs. Kurnitski et al. [4] showed in their article that the temperature difference between inside and outdoor conditions affects the thermal transmittance of glazing significantly. Petersen [5] calculated the heating energy of a building using a constant declared U-value of glazing and a more accurate dynamic U-value that varied for each hour of the climate year. Constant U-value could lead to significant under estimation of heating energy in cold climates and Petersen suggested using the described dynamic method for energy calculations.

Generally, energy specialists use standard window models with constant U-values in energy simulations, however, the thermal resistance of glazing varies depending on the outdoor temperature, wind speed and direction. Several types of dynamic simulation software such as IDA ICE 4.6 [6] allow creating detailed glazing models consisting of panes, cavities and shading devices. Detailed window models take the changes in weather conditions into account and calculate the energy balance of glazing more accurately than simple models.

The purpose of this study is to quantify the gap between the calculated energy need of a building model with simplified and detailed windows and suggest a method for reducing the gap. We composed a model of a detached house in the cold climate of Estonia and studied its energy needs with triple and quadruple windows. The size of glazed area in the south façade was also varied. Cases with closed windows were compared to a model where windows were opened to reduce over-heating and a case with cooling was added. We compared the difference in energy needs between models with simplified and detailed window, calculated and tested correction factors of standard window $\mathrm{U}$-values to reduce the gap in heating needs.

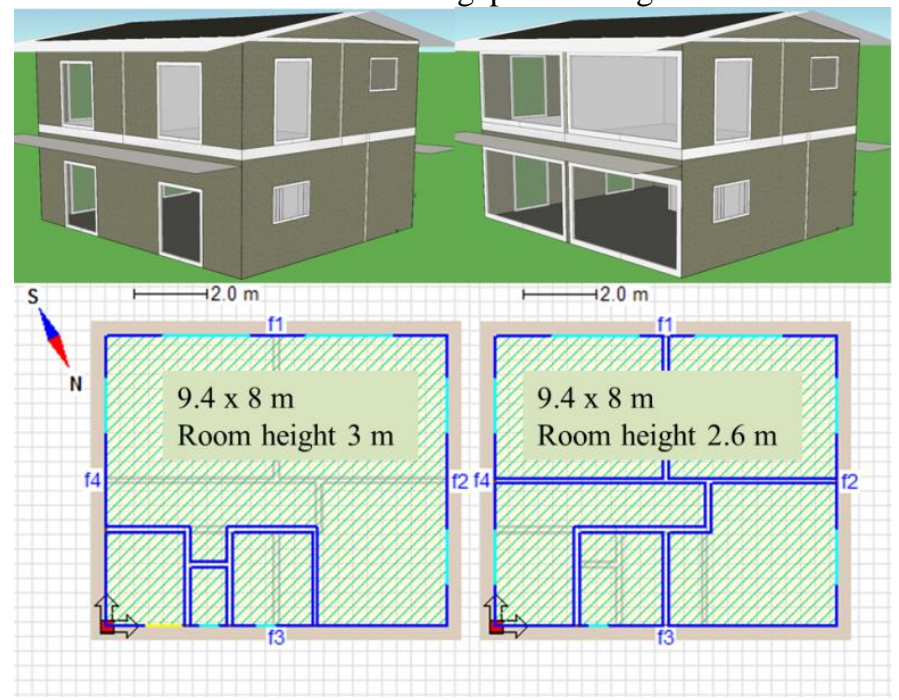

Fig. 1. The 3D view from south-east with minimum and maximum window sizes (top left and right respectively), first and second floor plans (bottom left and right respectively). The light blue lines on the perimeter of building envelope show the positioning of windows

\section{METHODS}

We conducted our analysis based on a model of a detached house (Fig. 1) in the following steps:

1. Energy simulations of the building with triple and quadruple glazing, varying window sizes, standard and detailed window models;

2. Determining the gap between the energy needs of the models with standard and detailed windows; 
3. Determining the correction factor for simplified triple glazing models and verifying the remaining mismatch in energy need calculations.

\section{A. Climate data}

The glazing properties in product sheets are generally given at standard conditions according to ISO 15099, i.e. at temperature difference of $20^{\circ} \mathrm{C}$ [7]. When room temperature is $21{ }^{\circ} \mathrm{C}$, then in static conditions the declared U-value corresponds to the actual one if outdoor temperature is $1{ }^{\circ} \mathrm{C}$. In case of lower temperatures, the glazing heat conductivity is higher. The outdoor temperatures are below $1{ }^{\circ} \mathrm{C}$ for most of the heating period in the cold climate of Estonia, which is described by the test reference year [8] (Fig.2). Therefore, the heat losses of detailed windows are generally larger than those of standard windows when the U-value of glazing is calculated continuously during simulations with detailed models.

\section{B. Detached house simulation model}

Energy simulations were conducted on the basis of a simulation model of a two-storey detached house with total heated area of $144.2 \mathrm{~m}^{2}$. The building has large windows in south and west orientations and the north façade has small windows. The plans and 3D view of the model are shown in Fig 1. The building is constructed of light-weight timber frame walls, floors and roof. Table I describes the areas and thermal conductivities of the building envelope elements. Each of the 10 rooms was modelled as a separate zone and the Estonian methodology for calculating the energy performance of buildings described in [9] was used. Well-validated simulation software IDA ICE 4.6 and Estonian reference year were used for performing energy simulations. Radiators (ideal heaters in the model), high-temperature cooling (ideal coolers in the model) and mechanical supply and exhaust ventilation with heat recovery were used. The usage factor of occupant and equipment was $60 \%, 10 \%$ for lighting and ventilation worked at all times. The initial data of simulation model is shown in Table II.

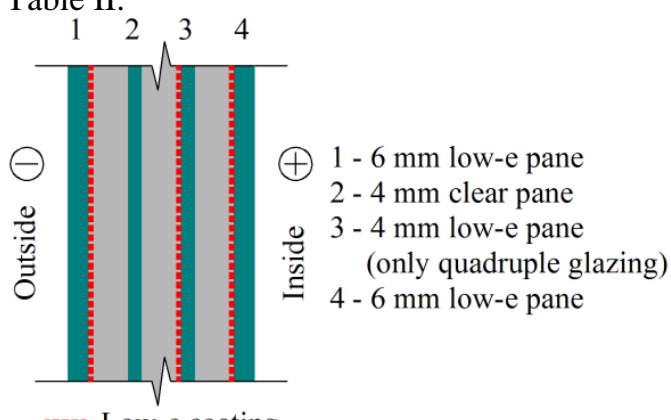

..... Low-e coating

Fig. 3. The construction of quadruple glazing and positioning on low-emissivity layers.

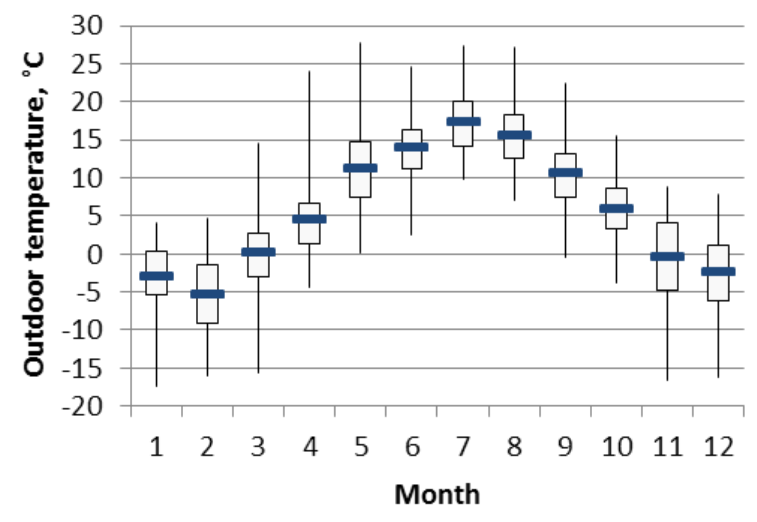

Fig. 2. The minimum, maximum and average temperatures of each month of Estonian test reference year. The average values are indicated with dark markers and the $25^{\text {th }}$ and $75^{\text {th }}$ percentiles are also presented.

TABLE I

THE DESCRIPTION OF THE INITIAL BUILDING ENVELOPE

\begin{tabular}{|l|c|c|c|c|}
\hline Structure & $\begin{array}{c}\mathrm{U} \text {-value, } \\
\mathrm{W} /\left(\mathrm{m}^{2} \mathrm{~K}\right)\end{array}$ & $\begin{array}{c}\text { Area, } \\
\mathrm{m}^{2}\end{array}$ & $\begin{array}{c}\text { Specific heat } \\
\text { loss H, W/K }\end{array}$ & $\begin{array}{c}\% \text { of } \\
\text { total }\end{array}$ \\
\hline External wall & 0.18 & 151.4 & 26.6 & 27.1 \\
\hline Roof & 0.15 & 75.7 & 11.4 & 11.6 \\
\hline Slab on ground & 0.23 & 72.5 & 16.8 & 17.1 \\
\hline Windows & 0.60 & 41.9 & 25.2 & 25.7 \\
\hline Doors & 1.1 & 2.1 & 2.2 & 2.2 \\
\hline Thermal bridges & - & - & 13.2 & 13.4 \\
\hline Infiltration & - & - & 2.9 & 3.0 \\
\hline Total/weighted average & 0.28 & 343.6 & 98.2 & 100 \\
\hline
\end{tabular}

a - Constant infiltration of $2.4 \mathrm{l} / \mathrm{s}$ was calculated using formula 1 (corresponding $\mathrm{q}_{50}=0.6 \mathrm{~m}^{3} / \mathrm{h}$ per building envelope $\mathrm{m}^{2}$ ).

TABLE II

INPUT DATA OF THE ZONES AND HVAC SYSTEMS FOR ENERGY CALCULATIONS

\begin{tabular}{|l|c|}
\hline Occupants, W/m ${ }^{2}$ & 3 \\
\hline Equipment, W/m ${ }^{2}$ & 3 \\
\hline Lighting, W/m ${ }^{2}$ & 8 \\
\hline Temperature setpoint for heating, ${ }^{\circ} \mathrm{C}$ & +21 \\
\hline Air flow rate, $1 /\left(\mathrm{s} \cdot \mathrm{m}^{2}\right)$ & 0.42 \\
\hline
\end{tabular}

TABLE III

THE PROPERTIES OF THE STUDIED WINDOW TYPES

\begin{tabular}{|l|c|c|}
\hline & Triple glazing & Quadruple glazing \\
\hline Glazing U-value ${ }^{\mathrm{a}}, \mathrm{W} /\left(\mathrm{m}^{2} \mathrm{~K}\right)$ & 0.55 & 0.32 \\
\hline Glazing g-value, - & 0.45 & 0.34 \\
\hline Gap between panes, $\mathrm{mm}$ & 18 & 12 \\
\hline Gas filling & $90 \%$ argon & $95 \%$ krypton \\
\hline Frame U-value, $\mathrm{W} /\left(\mathrm{m}^{2} \mathrm{~K}\right)$ & 0.8 & 0.8 \\
\hline Frame fraction of window area, $\%$ & 20 & 20 \\
\hline Total window U-value, $\mathrm{W} /\left(\mathrm{m}^{2} \mathrm{~K}\right)$ & 0.60 & 0.42 \\
\hline
\end{tabular}

a - The U-value of standard windows remained constant during simulations and is given according to calculations of ISO 15099:2003/E at internal and external temperature difference of $20^{\circ} \mathrm{C}$. The U-value was dynamic in case of detailed windows during simulations and was simulated also according to ISO 15099:2003/E. 
TABLE IV

GLASS PANE PROPERTIES OF DETAILED WINDOW MODELS

\begin{tabular}{|c|c|c|c|c|c|c|c|c|c|}
\hline \multirow[t]{2}{*}{ Pane } & \multirow{2}{*}{$\begin{array}{c}\text { Thermal } \\
\text { conductivity, } \\
\mathrm{W} /(\mathrm{mK})\end{array}$} & \multirow{2}{*}{$\begin{array}{c}\text { Total } \\
\text { shortwave } \\
\text { transmittance, } \\
-\end{array}$} & \multirow{2}{*}{$\begin{array}{c}\text { Total visible } \\
\text { transmittance, } \\
-\end{array}$} & \multicolumn{3}{|c|}{ Outside } & \multicolumn{3}{|c|}{ Inside } \\
\hline & & & & $\begin{array}{c}\text { Total } \\
\text { shortwave } \\
\text { reflectance, - }\end{array}$ & $\begin{array}{c}\text { Visible } \\
\text { reflectance, } \\
\text { - }\end{array}$ & $\begin{array}{c}\text { Longwave } \\
\text { emissivity, } \\
\text { - }\end{array}$ & $\begin{array}{c}\text { Total } \\
\text { shortwave } \\
\text { reflectance, - }\end{array}$ & $\begin{array}{c}\text { Visible } \\
\text { reflectance, } \\
\text { - }\end{array}$ & $\begin{array}{c}\text { Longwave } \\
\text { emissivity, } \\
-\end{array}$ \\
\hline Low-e & 1.0 & 0.62 & 0.88 & 0.23 & 0.06 & 0.89 & 0.27 & 0.05 & 0.03 \\
\hline Clear & 1.0 & 0.85 & 0.90 & 0.08 & 0.08 & 0.89 & 0.08 & 0.08 & 0.89 \\
\hline
\end{tabular}

The constant infiltration air flow rate was calculated with formula 1 [9]:

$q_{i}=\frac{q_{50}}{3.6 \cdot x} \cdot A$

where,

$\mathrm{q}_{\mathrm{i}} \quad$ infiltration air flow rate, $1 / \mathrm{s}$

$\mathrm{q}_{50}$ the air leakage rate of building envelope at pressure difference $50 \mathrm{~Pa}, 3 \mathrm{~m}^{3} /\left(\mathrm{h} \mathrm{m}^{2}\right)$

$\mathrm{x}$ factor for taking account the height of the building, 35 for buildings with 1 storey, -

A the total area of building envelope, $\mathrm{m}^{2}$

\section{Detailed and standard window models}

We analyzed highly transparent triple and quadruple glazing that had two and three low emissivity panes respectively. Fig. 3 displays the quadruple pane and the positioning of lowemissivity coatings. In case of triple glazing, in the middle there was a simple clear pane, the inner and outer panes had lowemissivity coatings. In IDA ICE we created detailed window models as it is described in Table III with pane properties shown in Table IV. IDA ICE uses the methodology of ISO 15099 [7] to calculate the properties of detailed window models. The window properties shown in Table III were used as constant values in standard window models.

\section{Simulated cases}

The standard and detailed windows were compared using all combinations of the following variables:

- Triple or quadruple glazing

- Window width $1.8,2.0, \ldots, 4.6$ meters

- First floor window height 2.2, 2.3, 2.4 or 2.5 meters, second floor windows were 0.1 meters lower in each case

- Window opening and cooling:

a) Windows were closed at all times, no cooling or

b) From 6 p.m. to 6 a.m. windows were opened $20 \%$ if room temperature exceeded $27^{\circ} \mathrm{C}$, no cooling or

c) From 6 p.m. to 6 a.m. windows were opened $20 \%$ if room temperature exceeded $25^{\circ} \mathrm{C}$ and the cooling system setpoint was at $27^{\circ} \mathrm{C}$.

\section{E. Predicting the correction factor for the $U$-value of standard window model}

The simulations with standard and detailed window models result in different heating energy needs. Acquiring detailed information about window panes from the manufacturers can be currently difficult and time consuming for energy efficiency specialists. Therefore, we tested if using a correction factor for the U-value of standard window models could minimize the error in simulation results. Based on the differences in simulation results and the proportion of glazing in the heat losses of the building, we predicted what the suitable correction factor for triple windows should be with the following methodology.

The proportion of glazing in the building heat losses was calculated according to formula 2 using values from Table I.

$\frac{H_{G L}}{H_{T O T}}=\frac{\left(1-F_{f}\right) \cdot A_{W I N} \cdot U_{G L}}{A_{W I N} \cdot U_{W I N}+A_{E W} \cdot U_{E W}+H_{\text {other }}}$

where

$\mathrm{H}_{\mathrm{GL}} \quad$ specific heat loss of glazing, W/K

$\mathrm{H}_{\text {Tот }}$ total specific heat loss of the building, W/K

$\mathrm{F}_{\mathrm{f}} \quad$ frame fraction of total window area, -

AwIN area of windows, $\mathrm{m}^{2}$

$\mathrm{U}_{\mathrm{GL}} \quad$ glazing $\mathrm{U}$-value at standard conditions, $\mathrm{W} /\left(\mathrm{m}^{2} \mathrm{~K}\right)$

$\mathrm{U}_{\text {WIN }}$ window U-value at standard conditions, $\mathrm{W} /\left(\mathrm{m}^{2} \mathrm{~K}\right)$

$\mathrm{A}_{\mathrm{EW}} \quad$ External window area without windows, $\mathrm{m}^{2}$

$\mathrm{U}_{\mathrm{EW}} \quad$ external wall $\mathrm{U}$-value, $\mathrm{W} /\left(\mathrm{m}^{2} \mathrm{~K}\right)$

$\mathrm{H}_{\text {other }}$ specific heat loss of slab on ground, roof, doors, thermal bridges, infiltration and any other components of heat loss $\mathrm{W} / \mathrm{K}$

The correction factor for standard window glazing U-value could be used to minimize the gap in simulated energy needs. We predicted it for each case with formula 3 :

$f_{\text {corr }}=\left(\frac{Q_{D E T}}{Q_{S T D R}}-1\right) \cdot \frac{H_{G L}}{H_{T O T}}+1$

Where

$\mathrm{f}_{\text {corr }} \quad$ correction factor, -

QDET heating energy in case of detailed windows, $\mathrm{kWh}$

QSTDR heating energy in case of standard windows, $\mathrm{kWh}$

$\mathrm{H}_{\mathrm{GL}} \quad$ specific heat loss of glazing, W/K

$\mathrm{H}_{\text {тот }}$ total specific heat loss of the building, W/K

The calculated correction factors varied (see section III.B) and therefore we simulated all standard triple window cases with glazing U-value correction factors 1.1, 1.15, 1.2 and 1.25. The correction factor resulting in the smallest difference between the heating energy of detailed and standard window models was suggested for using in energy calculations with simple window models. 


\section{RESULTS}

\section{A. Energyneeds}

The comparison of glazing models show that in case of triple glazing standard window models resulted in lower building heating need by $1.4-2.6 \mathrm{kWh} / \mathrm{m}^{2}$ of the heated area (Fig. 4). In case of quadruple windows, the heating need with standard windows could be lower by up to $0.2 \mathrm{kWh} / \mathrm{m}^{2}$ or higher by up to $0.1 \mathrm{kWh} / \mathrm{m}^{2}$. The differences are higher in case of smaller window areas and when there is no window opening and cooling. The window-to-wall ratio (WWR) resulting in lowest heating need did not depend on the window model used in case of quadruple glazing, however with triple windows the optimal window area differed depending on the glazing model used.

The simulations with detailed triple windows resulted in lower optimal window-to-wall areas than standard windows.
Window opening and adding a cooling system also lowered the optimal window size. The optimal WWR of triple windows was between $39 \%$ and $76 \%$, in case of quadruple windows the gap between optimal window sizes was smaller and minimum heating need was achieved with WWR between $76 \%$ and $86 \%$.

The cooling need was higher with standard windows in all cases with differences between 1.1 and $3.6 \mathrm{kWh} / \mathrm{m}^{2}$ in case of triple windows and 0.5 to $2.0 \mathrm{kWh} / \mathrm{m}^{2}$ in case of quadruple windows (Fig. 5). The differences increased with larger windows. As the differences in cooling energy were larger in heating energy, then models with standard windows and cooling had generally higher total energy need than similar models with detailed windows (Fig. 6).

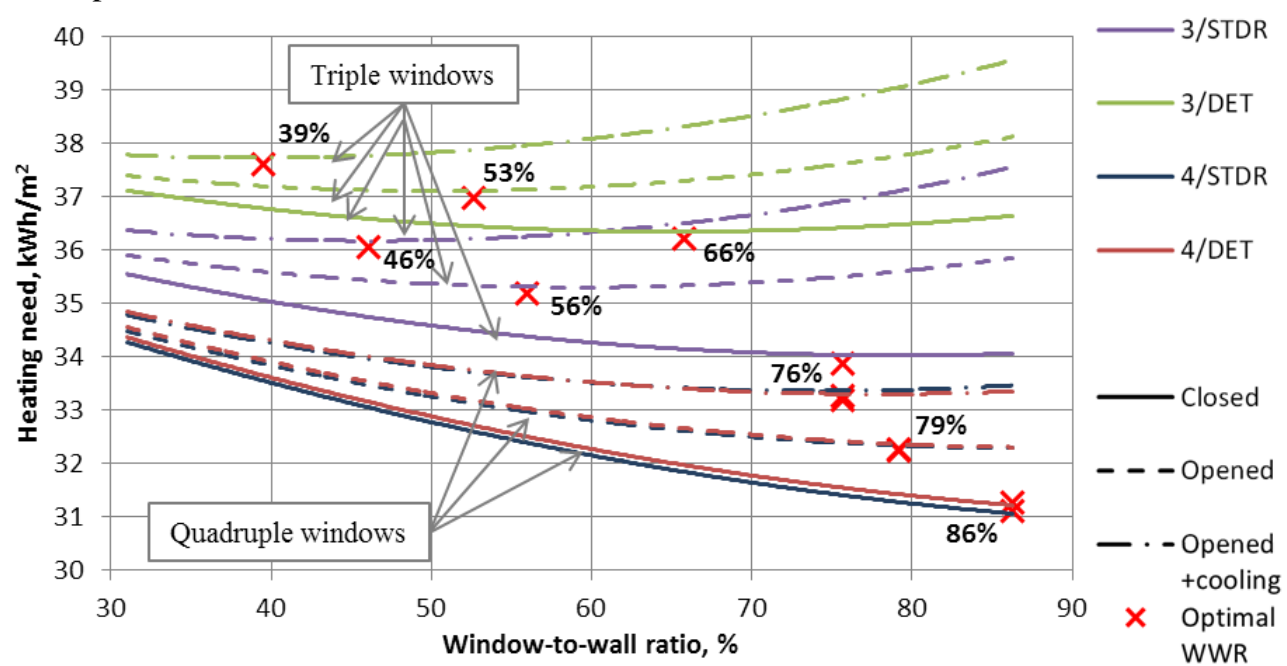

Fig. 4. The heating need and optimal window -to-wall ratio of studied window models with different control strategies and with or without cooling.

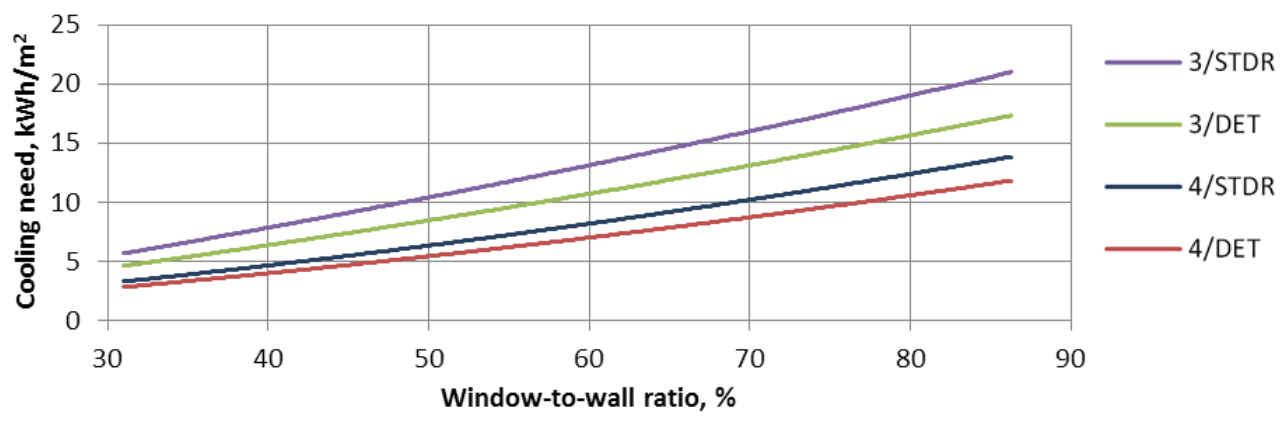

Fig. 5. The cooling need of the studied window models with different window-to-wall ratios.

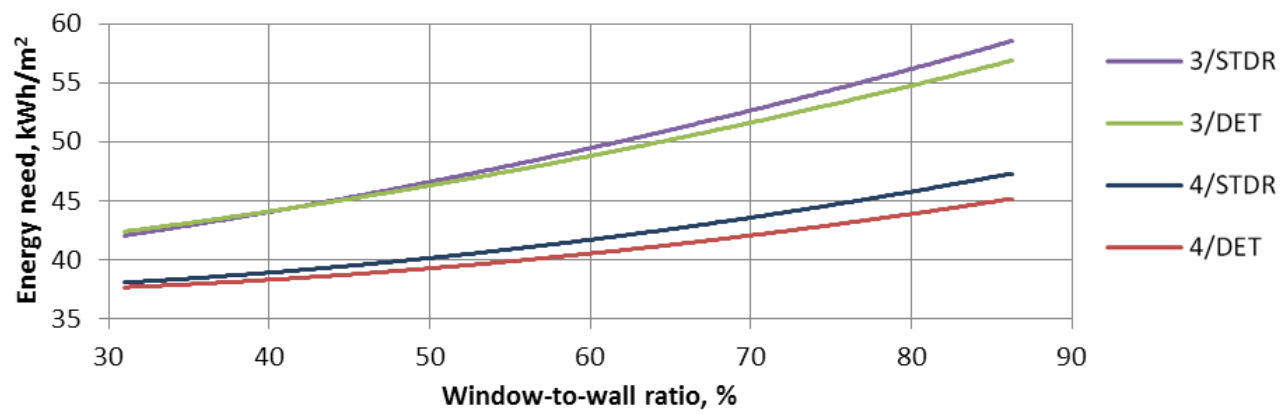

Fig. 6. The sum of heating and cooling needs of the studied window models with different window-to-wall ratios. 


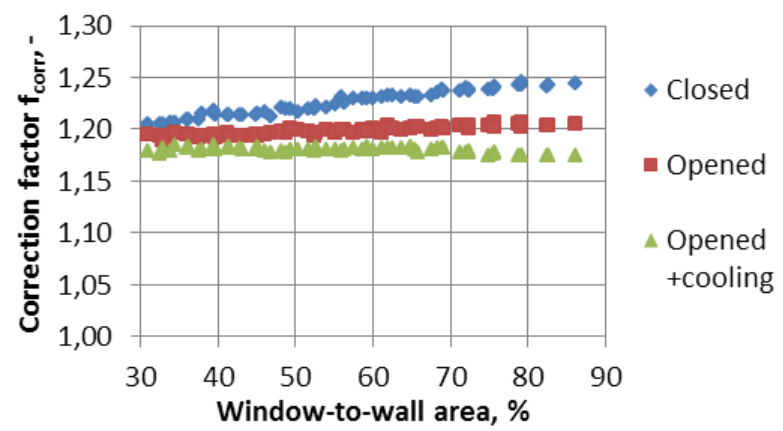

Fig. 7. The predicted correction factors for standard triple windows to minimize the gap in energy need with detailed window models.

\section{B. Correction factors}

The standard window U-value correction factors for minimizing the gap in energy need with detailed window models were calculated based on the proportion of glazing in total heat losses of the detached house and the difference in the heating needs of models with standard and detailed windows. The correction factor ranged between 1.17 and 1.25 depending on the case and the factors were highest in case of closed windows and lowest if window opening was allowed and a cooling system was used (Fig. 7). Based on the calculated correction factors and adjustments during the work, we experimented with the following corrections factors to standard triple glazing $\mathrm{U}$-values $-1.1,1.15,1.2$ and 1.25.

\section{Minimizing the gap in energy need}

The heating need without any correction in the glazing Uvalues was with standard triple glazing models $3.7 \%$ to $7.0 \%$ lower than with detailed glazing models and the difference increased in case of larger windows (Fig. 8). Also the differences in heating energy were larger with no window opening and cooling. The gaps in cooling need were from $21.1 \%$ to $23.2 \%$ in cooling need with standard windows resulting in higher cooling energy use. The total energy need of heating and cooling was smaller by up to $0.7 \%$ with small standard windows and larger by up to $2.8 \%$ with large standard windows.

The comparison of simulated energy needs of the building model with standard and detailed windows shows that using correction factors could reduce the difference remarkably in case of building with heating only. Multiplying standard window U-value with correction factor 1.15 resulted in lowest difference in heating energy. In closed window cases, the differences in heating need remained within $0.1 \%$ (Fig. 8 part a). When windows were opened to reduce over-heating, then correction factor 1.15 resulted in $0.2-0.8 \%$ higher heating need in case of standard glazing (Fig. 8 part b). The differences in the heating need were highest in case of building models with cooling correction factor 1.15 (Fig 8 part c), however, it is not important since we should also observe the cooling energy.
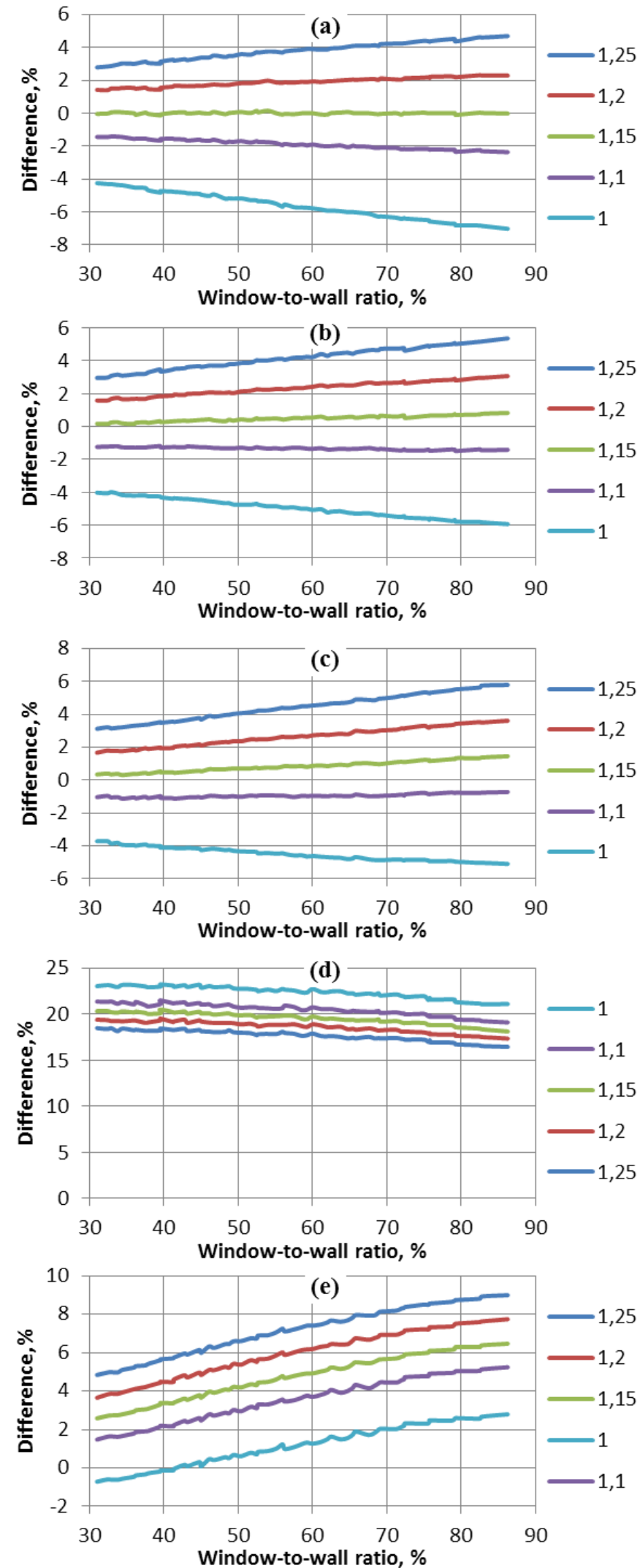

Fig. 8. The differences in energy need of standard triple window models from detailed window models in case of analyzed correction factors. If difference is over 0 , then standard models result in higher energy need than detailed models. Code: $\mathrm{a}$ - heating need, closed windows; $\mathrm{b}$ - heating need, opened windows without cooling; $\mathrm{c}$ - heating need, opened windows and cooling; $\mathrm{d}-$ cooling need; e - energy need of models with cooling. 
Increasing the U-value of standard window models decreased the gap in cooling energy, however, the difference remained above $16 \%$ in all cases (Fig 8 part d). As mentioned before, the difference in cooling energy is generally higher than in heating energy, if standard and detailed glazing models are compared. Therefore, the correction factors did not decrease the difference in total energy need in case of buildings with cooling (Fig 8 part e). Standard glazing U-value correction factors could only be used in case of building with only cooling and the correction factor 1.15 should be used for triple glazing with Uvalue $0.55 \mathrm{~W} /\left(\mathrm{m}^{2} \mathrm{~K}\right)$ in a cold climate typical of Estonia.

\section{DISCUSSION AND CONCLUSIONS}

Energy simulation based façade analysis requires using precise input data and correct methodology to reach adequate results. Our study shows that in the cold climate of Estonia detailed modelling of glazing results in higher heat losses and lower cooling needs than simplified models. The heating energy needs differed by up to $7 \%$ with compared window models and the gap was even larger in cooling energy, which reached $23 \%$. Triple glazing had significant mismatch in the energy use of standard and detailed models, while the simulated energy with quadruple glazing corresponded well. Also the optimal window-to-wall ratios differed by up to $10 \%$ in case of triple windows. Therefore using standard window models might lead to inadequate façade design.

In the building without cooling the deviation was possible to compensate, but buildings with both heating and cooling were challenging as the total energy need can be either smaller or larger when simplified and detailed models are compared. Therefore, correcting only the U-value of standard glazing cannot be used in such cases. It has to be studied further whether using additional correction factor e.g. for $\mathrm{g}$-values could reduce the gap in the simulated energy. Right now it can be recommended to use detailed window models for mechanically cooled buildings in cold climates.

In case of buildings without cooling simulating standard glazing over estimates the optimal window size, which in addition to inaccurate energy use also increases over-heating during summer periods. The study results suggest increasing the U-value on standard efficient triple glazing by a factor of 1.15 in the Estonian climate. However, it must not be forgotten that different correction factors should be used with other glazing types and climates.

\section{ACKNOWLEDGEMENTS}

The research was supported by the Estonian Research Council, with Institutional research funding grant IUT1-15, with Personal research funding grant PUT-652, and with a grant of the European Union, the European Social Fund, Mobilitas grant No MTT74.

\section{REFERENCES}

[1] M. Thalfeldt, E. Pikas, J. Kurnitski and H. Voll, "Façade design principles for nearly zero energy buildings in a cold climate" Energy and Buildings, Vol. 67, 2013, pp. 309-321.

http://dx.doi.org/10.1016/j.enbuild.2013.08.027

[2] E. Pikas, M. Thalfeldt and J. Kurnitski, "Cost optimal and nearly zero energy building solutions for office buildings" Energy and Buildings, Vol. 74, 2013, pp. 30-42. http://dx.doi.org/10.1016/j.enbuild.2014.01.039

[3] M.-L. Persson, A. Roos and M. Wall, "Influence of window size on the energy balance of low energy houses" Energy and Buildings, Vol. 38, 2006, pp. 181-188. http://dx.doi.org/10.1016/j.enbuild.2005.05.006

[4] J. Kurnitski, J. Jokisalo, J. Palonen, K. Jokiranta and O. Seppänen, "Efficiency of electrically heated windows" Energy and Buildings, Vol. 36, 2004, pp. 1003-1010. http://dx.doi.org/10.1016/j.enbuild.2004.06.007

[5] S. Petersen, "The effect of weather data on glazing U-value in building performance simulation" presented at 10th Nordic Symposium on Building Physics, Lund, Sweden, June 2014.

[6] IDA-ICE, IDA Indoor Climate and Energy 4.6. http://equa.se/en/ida-ice

[7] ISO Standard 15009 (2003). Thermal performance of windows, doors and shading devices - Detailed calculations. International Organization for Standardization.

[8] T. Kalamees and J. Kurnitski, "Estonian test reference year for energy calculations" Proceedings of the Estonian Academy of Sciences Engineering, Vol. 12, 2006, pp. 40-58.

[9] Estonian Government Ordinance No. 68 Energiatõhususe miinimumnõuded. (Minimum requirements for energy performance of buildings) (30.08.2012); RT I, 05.09.2012, 4, 2012. 